\title{
The role of sigma-I receptors in the pathophysiology of neuropsychiatric diseases
}

This article was published in the following Dove Press journal:

Journal of Receptor, Ligand and Channel Research

16 December 2009

Number of times this article has been viewed

\section{Masatomo Ishikawa \\ Kenji Hashimoto}

Division of Clinical Neuroscience, Chiba University for Forensic Mental Health, Chiba, Japan
Correspondence: Kenji Hashimoto Division of Clinical Neuroscience, Chiba University for Forensic Mental Health, Chiba 260-8670, Japan

Tel +8I 432262149

Fax +81432262150

Email hashimoto@faculty.chiba-u.jp
Abstract: The endoplasmic reticulum protein sigma-1 receptors, first regarded as opioid receptors and later confused as the phencyclidine (PCP) binding sites of the N-methyl-D-aspartate (NMDA) receptor, are now confirmed to be independent receptors. They are involved in the modulation of various neurotransmitter systems and have a high affinity for diverse classes of psychotropic drugs. Accumulating evidence suggests that the sigma-1 receptors are implicated in higher-ordered brain functions and play important roles in the pathophysiology of neuropsychiatric diseases such as schizophrenia, depression, anxiety disorders, and dementia. Recently, sigma-1 receptors have been shown to function at the molecular level as "receptor chaperones." This mechanism may unify the explanation of the role of sigma-1 receptors in the pathophysiology of neuropsychiatric diseases. With the development of the positron emission tomography (PET) ligand $\left[{ }^{11} \mathrm{C}\right] \mathrm{SA} 4503$, it has become possible to visualize sigma-1 receptors and estimate the sigma-1 receptor occupancy of drugs in the human brain. This approach may provide additional information on the function of sigma- 1 receptors. This article reviews the function of sigma-1 receptors and attempts to reinterpret their role in the pathophysiology of neuropsychiatric diseases based on their new description as "receptor chaperones."

Keywords: sigma-1 receptor, schizophrenia, major depressive disorder, obsessive-compulsive disorder, Alzheimer's disease, positron emission tomography

\section{Introduction}

2007 was a breakthrough year in the research on sigma-1 receptors. Hayashi and $\mathrm{Su}$ proposed the novel concept of "receptor chaperones" to explain the physiological roles of sigma-1 receptors. ${ }^{1}$ In order to understand the impact of this report, we must first look back on the history of sigma-1 receptor research.

Sigma receptors were first mistakenly proposed to be a subclass of opioid receptors. While investigating the responses of benzomorphans in the nondependent chronic spinal dog, Martin and colleagues ${ }^{2}$ reported that, unlike morphine, which causes analgesic actions, ketocyclazocine and SKF10047 (N-allylnormetazocine) set off different psychological reactions. Taking the initial S of SKF10047, which elicits psychotomimetic effects, and exchanging it for its Greek equivalent, Martin and colleagues gave the name "sigma receptor" to the corresponding subtype opioid receptor. ${ }^{2}$ Subsequent studies revealed that behaviors induced by SKF10047 were resistant to the classical opiate receptor antagonists naloxone ${ }^{3}$ and naltrexone,${ }^{4}$ thus differentiating the sigma receptors from classic opiate receptors.

However, because SKF10047 interacts with many binding sites and because its dextrorotatory analogue, (+)-SKF10047 (Figure 1), possesses phencyclidine (PCP)-like 
properties, sigma receptors were next misunderstood as PCP binding sites. The PCP binding site was later found to be an ionophore of the N-methyl-D-aspartate (NMDA) receptor. ${ }^{5}$ Further autoradiographic studies using more selective radioligands demonstrated that sigma receptors and PCP binding sites show different distributions, ${ }^{6}$ leading to the conclusion that the sigma receptor is a unique binding site. ${ }^{7}$

\section{Characteristics of sigma-I receptors}

Binding studies and pharmacological activity studies show that the sigma receptor consists of at least two subtypes, sigma-1 and sigma-2. ${ }^{7,8}$ In 1996, the sigma-1 receptor was successfully cloned and its molecular conformation was revealed..$^{9}$ The sigma- 1 receptor is a 223 amino acid protein with two transmembrane domains (Figure 2), and although it<smiles></smiles>

(+)SKF10047<smiles>CCCCN1CCN(CCCc2ccccc2)CC1</smiles><smiles>COc1ccccc1OC</smiles><smiles>O=C(OCCN1CCOCC1)C1(c2ccccc2)CCCCC1</smiles>

SA4503 (cutamesine)

PRE084<smiles>O=C(CCCN1CCC(O)(c2ccc(Cl)cc2)CC1)c1ccc(F)cc1</smiles>

Haloperidol<smiles>[R17]C(=O)O[Na]</smiles><smiles>OC(CCCN1CCN(c2ncc(F)cn2)CC1)c1ccc(F)cc1</smiles><smiles>OC(CN1CCC(Cc2ccc(F)cc2)CC1)c1ccc(Cl)cc1</smiles>

Eliprodil (SL-82.0715)

BMY14802<smiles>CCC(C/C=C/c1ccccc1)(c1ccccc1)N(C)CC1CC1</smiles>

Igmesine<smiles>COc1ccc(N2C[C@H](CN3CCC(O)(c4ccc5c(c4)OCO5)CC3)OC2=O)cc1</smiles>

Panamesine (EMD57445) 


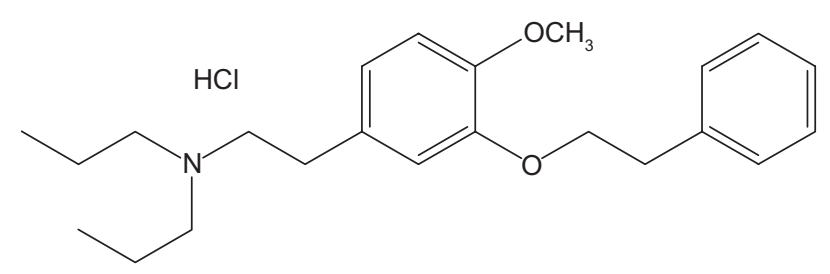

NE-100<smiles>CN(C)CCN(C)CCc1ccc(Cl)c(Cl)c1</smiles>

BD-1047

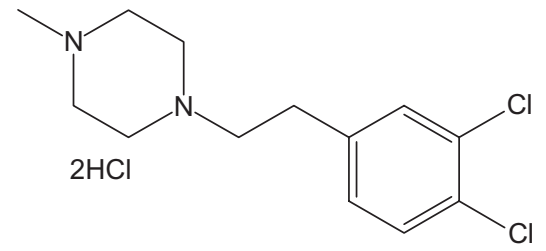

BD-1063

Figure I Chemical structures of sigma-I receptor ligands.

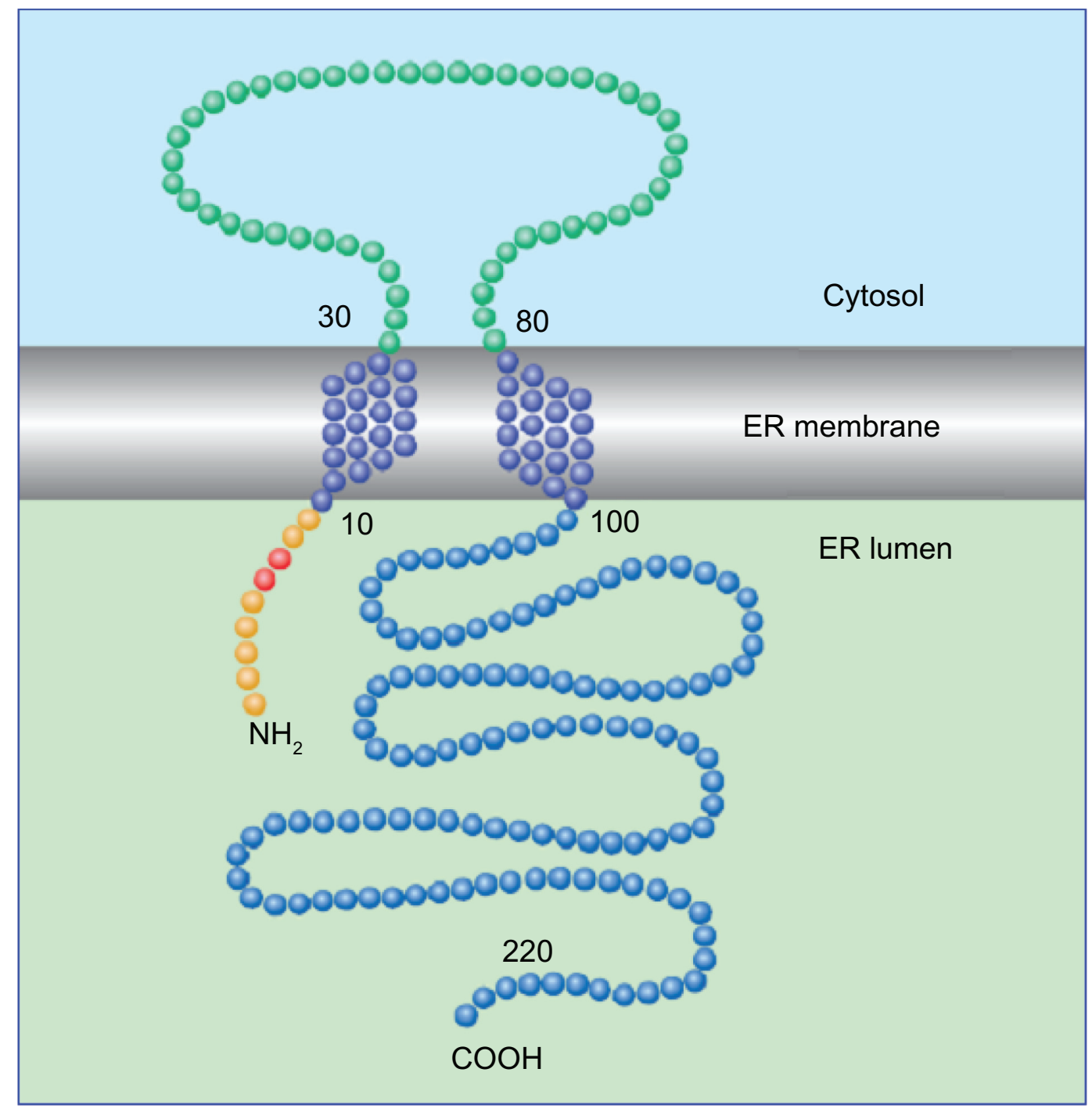

Figure 2 Predicted structure of sigma-I receptor. Predicted molecular structure of the sigma-I receptor. Circles represent amino acids. A slight modification from the figure by Hayashi and colleagues.' 
has no homology to any other mammalian proteins, it shares a $30 \%$ identity with a yeast C8-C7 sterol isomerase. ${ }^{9}$ Sigma-1 receptors mainly reside on the endoplasmic reticulum (ER), and they dynamically translocate inside cells. ${ }^{10,11}$ Further studies revealed that sigma-1 receptors are particularly enriched at the mitochondria-associated ER membrane. ${ }^{1}$

As mentioned above, Hayashi and $\mathrm{Su}^{1}$ proposed that sigma-1 receptors function as "receptor chaperones." In the steady state, sigma-1 receptors form a complex with another molecular chaperone, BiP. By forming this complex, sigma-1 receptors are inhibited from activation. A decrease of $\mathrm{Ca}^{2+}$ in the ER causes the sigma-1 receptor to part from the BiP complex, and thus the sigma-1 receptor becomes an activated chaperone. The activated sigma-1 receptor then binds to the inositol 1-4-5-triphosphate $\left(\mathrm{IP}_{3}\right)$ receptor. $\mathrm{IP}_{3}$ receptors are very unstable proteins and are easily degraded by proteasomes, but the binding of sigma-1 receptor stabilizes them. As a result of this stabilization, $\mathrm{Ca}^{2+}$ flows into the mitochondria via voltage-dependent anion channels. This inflow of $\mathrm{Ca}^{2+}$ into the mitochondria activates the intramitochondrial tricarboxylic acid (TCA) cycle, which induces cell-hypermetabolization, and ultimately results in neuroprotection and neurite outgrowth.,12 Such neuroprotection and neurite outgrowth are thought to contribute to the improvement of various neuropsychiatric diseases (Figure 3). Thus, sigma-1 receptors are assumed to serve as a regulator of adenosine triphosphate (ATP) production and bioenergetics within the cell. ${ }^{12}$ The ability to detach BiP from sigma-1 receptors discriminates sigma-1 agonists from antagonists (Table 1). ${ }^{1}$

\section{Neuropsychiatric disorders and sigma-I receptors}

We will next discuss the role of the sigma-1 receptors in the pathophysiology of some major neuropsychiatric diseases (Table 2).

\section{Schizophrenia}

Schizophrenia is a major psychiatric disorder which shows positive symptoms (eg, hallucinations and delusions), negative symptoms (eg, affective flattening, alogia, or avolition), and cognitive impairments (eg, severe deterioration of concentration and memory). It has been reported that approximately 2.4 million American adults or about $1.1 \%$ of the population aged 18 years and older in a given year ${ }^{13}$ have schizophrenia using the DSM-IV classification. Although schizophrenia itself has been recognized for centuries, pharmaceutical treatment only began in the 1950 s with the development of chlorpromazine, which mainly targeted positive symptoms. Following chlorpromazine, many other pharmacological agents were developed, most of which are now grouped as typical antipsychotics. These agents were dopamine $\mathrm{D}_{2}$ receptor antagonists and although they showed therapeutic performance for positive symptoms, dose-dependent extrapyramidal symptoms (EPS) were inevitable. Atypical antipsychotics with lower rates of EPS were introduced in the 1980 s, resulting in a partial recovery of negative symptoms in addition to a decrease in positive symptoms. Despite these advances, however, the rehabilitation rates of schizophrenics are still low.

Because SKF10047 induced psychotomimetic effects, sigma-1 receptors were first considered to be intimately associated with schizophrenia. In fact, there are reports showing a reduction of sigma-1 receptors in the brains of schizophrenic patients postmortem, ${ }^{14,15}$ and the typical and widely used antipsychotic haloperidol (Figure 1) has a very high affinity for sigma-1 receptors. ${ }^{3,16}$ Interestingly, it is also reported that sigma-1 receptors are engaged in modulating NMDA-type glutamate receptors, ${ }^{17-19}$ which might be involved in the pathophysiology of schizophrenia. ${ }^{20-26}$

Clinical trials with rimcazole, BMY 14802, eliprodil (SL-82.0715) and panamesine (EMD57445) (Figure 1) have been conducted. ${ }^{27}$ Unfortunately, most of these ligands show poor efficacy for the treatment of schizophrenia, and for acute symptoms their effects can even be negative. ${ }^{27}$ However, an open label study for eliprodil, performed with chronic schizophrenic patients with predominantly negative symptoms, improved the negative symptoms as assessed by the positive and negative syndrome scale. ${ }^{28}$ Panamesine improved both positive and negative symptoms, ${ }^{29}$ but as the metabolite of panamesine was found to have potent antidopaminergic properties which might explain these improving effects, this information must be taken with caution. ${ }^{27}$

The prominence of cognitive impairments as core symptoms of schizophrenia has recently been reconsidered. ${ }^{30}$ A number of basic research studies have demonstrated the role of sigma-1 receptors in schizophrenic cognitive impairments. PCP is known to induce negative symptoms and cognitive impairments in healthy individuals, and is therefore used in animal models of schizophrenia. We reported that repeated administration of PCP caused the reduction of sigma-1 receptors in the frontal cortex ${ }^{31}$ and the hippocampus ${ }^{32}$ in the mouse brain, consistent with a previous report ${ }^{14}$ on postmortem brain samples from schizophrenia patients. The PCP-induced cognitive impairments could be improved by subsequent subchronic administration of fluvoxamine but not 


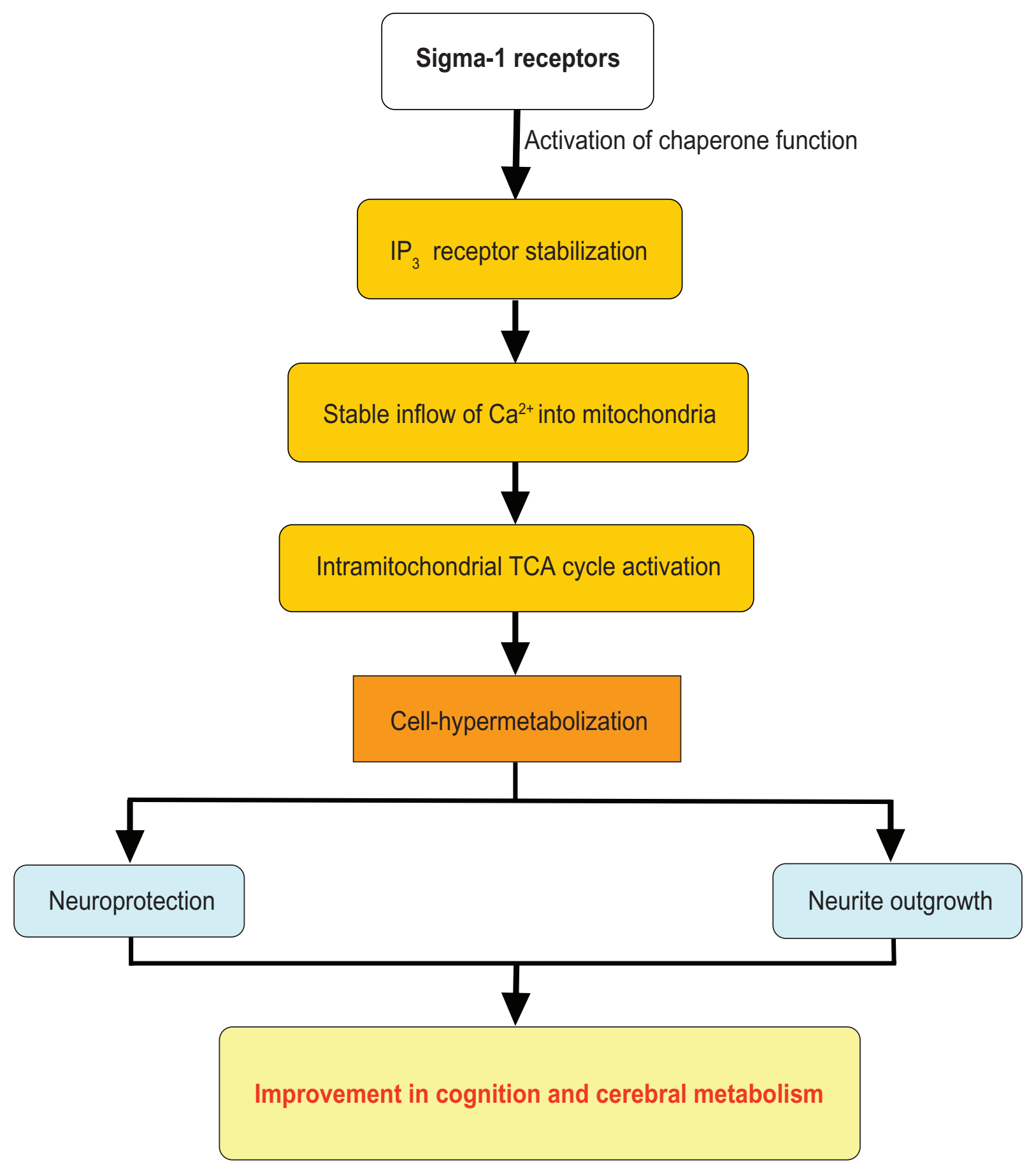

Figure 3 Mechanism of action of sigma-I receptor agonists. Postulated mechanism of sigma-I receptors.

paroxetine or sertraline..$^{31,33}$ In addition, the selective sigma-1 agonist SA4503 or neurosteroid dehydroepiandrosterone-sulfate (DHEA-S) ${ }^{33}$ improved PCP-induced cognitive deficits in mice. These effects were antagonized by coadministration of the selective sigma-1 receptor antagonist NE-100 (Figure 1), ${ }^{34}$ suggesting that sigma-1 receptor agonism of these drugs might be involved in the mechanism of action. These results indicate that sigma-1 receptor agonists would be potential therapeutic drugs for the treatment of cognitive impairments in schizophrenia.

Adjunctive medication of fluvoxamine, a sigma-1 receptor agonist (Table 1), has been reported to improve primary negative symptoms in chronic schizophrenia patients who had been treated with antipsychotics..$^{35,36}$ Furthermore, Iyo and colleagues ${ }^{37}$ reported a case that demonstrated the efficacy of $50 \mathrm{mg} /$ day-fluvoxamine, but not $20 \mathrm{mg} /$ day-paroxetine, 
Table I Substances related to sigma-I receptors'

\begin{tabular}{lll}
\hline $\begin{array}{l}\text { Agonist } \\
\text { (activation) }\end{array}$ & $\begin{array}{l}\text { Antagonist } \\
\text { (inactivation) }\end{array}$ & No effect \\
\hline (+) Pentazosine & NE-100 & Paroxetine \\
$(+)$ SKFI0047 & Haloperidol & Risperidone \\
Fluvoxamine & Sertraline & Physostigmine \\
Igmesine & BDI047 & \\
Pregnenolone-S & BDI063 & \\
DHEA-S & & \\
Donepezil & & \\
PPBP & & \\
SA4503 & & \\
PRE-048 & & \\
\hline
\end{tabular}

Notes: Substances classified based on its action towards the binding of BiP and sigma-I receptor. Substances which disengage sigma-I receptors from $\mathrm{BiP}$ are agonists. Abbreviations: DHEA, dehydroepiandrosterone; $\mathrm{S}$, sulfate.

on cognitive deficits in a schizophrenic patient treated with risperidone (no affinity at sigma- 1 receptors).$^{38}$ Therefore, there is need of a further double-blind, placebo-controlled study of the effects of adjunctive fluvoxamine on cognitive impairments in patients with schizophrenia.

There are a few reports indicating that polymorphisms of the sigma-1 receptor gene (SIGMAR1) are associated with schizophrenia. Two functional polymorphisms of SIGMAR1, GC-241-240-TT and Gln2Pro, were identified and reported to have a significant association with schizophrenia. ${ }^{39}$ Subsequent studies failed to confirm this, ${ }^{40,41}$ but a study by Takizawa and colleagues ${ }^{42}$ using 52-channel near-infrared spectroscopy showed a significant association between the prefrontal hemodynamic response during a verbal fluency task and the Gln2Pro polymorphism of the sigma-1 receptor gene in schizophrenia patients.

\section{Major depressive disorder}

Major depressive disorder is a common mood disorder characterized by depressed mood, insomnia, irritation, and cognitive deficits, and in severe cases can lead to suicide. Major depressive disorder is the leading cause of disability in the United States for ages 15 to 44 years $^{43}$ and affects approximately 14.8 million American adults or about $6.7 \%$ of the USA population aged 18 years and older in a given year. ${ }^{44}$

A relationship between sigma-1 receptors and depression was first identified by Matsuno and colleagues ${ }^{45}$ using the forced swimming test (FST), which is a standard animal model of depression. Sigma-1 ligands such as igmesine ${ }^{46}$ and SA4503 ${ }^{47}$ (Figure 1) show antidepressive effects in the FST, and these effects are antagonized by the sigma-1 antagonists BD1047 or NE-100 (Figure 1). Interestingly, the antidepressant-like effect of SA4503 was achieved following a single administration of the drug. Subsequently, the rapid antidepressant-like action of SA4503 was replicated by different sigma-1 receptor agonists. ${ }^{48,49}$ Furthermore, electrophysiological studies demonstrated a rapid antidepressant-like action for sigma-1 receptor agonists. ${ }^{50}$ In addition, sigma-1 receptor knock-out mice show longer immobility time in the FST, indicating the depression-like phenotype of the mice. ${ }^{51}$ We have reported that fluvoxamine, but not sertraline or paroxetine, potentiated nerve growth factor (NGF)-induced neurite outgrowth in PC12 cells. ${ }^{52}$ Other sigma-1 receptor agonists such as SA4503, 4-phenyl-1-(4-phenylbutyl)piperidine (PPBP), and DHEA-S (Figure 1) also exhibited the potentiating effect, and all the outgrowth effects were also antagonized by co-incubation with NE-100. ${ }^{52}$ This finding is consistent with the sigma-1 receptor's "receptor chaperone" mechanism, which ultimately results in neurite outgrowth (Figure 3). Taken together, these results suggest that sigma-1 receptor agonists have rapid antidepressant-like actions, ${ }^{12}$ unlike existing antidepressants which have a delayed onset of action of 2-6 weeks. A phase II study of SA4503 (cutamesine) in patients with major depression is currently underway.

Neurosteroids are hormones produced in the central and peripheral neurons, and were first reported by Baulieu. ${ }^{53}$ It was shown that the brain concentrations of the neurosteroids DHEA, DHEA-S, pregnenolone, and pregnenolone sulfate (Figure 1) were far greater than those found in the circulation. Furthermore, their concentrations in the brain remained high after adrenalectomy and orchiectomy, suggesting that these steroids did not originate from steroidogenic tissue but rather originated through local brain synthesis. As these neurosteroids have moderate affinity towards sigma-1 receptors, they are considered to be endogenous ligands. Some neurosteroids show antidepressive activity in the FST, and NE-100 has been shown to antagonize the improvements, ${ }^{54,48}$ indicating that the antidepressive effect of these drugs is brought on by sigma-1 receptors. In consideration of these results, it is likely that sigma-1 receptor agonists would be effective as rapid acting antidepressant drugs for major depression. ${ }^{55-59}$

Psychotic (or delusional) major depression is a challenging disease which has, in addition to depressive symptoms, psychotic delusions such as delusions of poverty or sin and has significantly higher mortality than nonpsychotic major depression. ${ }^{60,61}$ This condition is associated with much greater dysfunction of cognitive ability than major depression. 
Table 2 Summarization of psychiatric diseases and its association with sigma-I receptors

\begin{tabular}{|c|c|c|c|}
\hline Mental disorders & $\begin{array}{l}\text { Main related } \\
\text { substances }\end{array}$ & & Associating events \\
\hline \multirow[t]{2}{*}{ Schizophrenia } & $\begin{array}{l}\text { Haloperidol } \\
\text { Eliprodil }\end{array}$ & Preclinical & $\begin{array}{l}\text { - Sigma-I ligands modulate NMDA receptors which } \\
\text { effect dopamine regulation }{ }^{17-19}\end{array}$ \\
\hline & $\begin{array}{l}(\mathrm{SL}-82.07 / 5) \\
\text { Fluvoxamine }\end{array}$ & Clinical & $\begin{array}{l}\text { - Reduction of sigma-I receptors in the } \\
\text { postmortem schizophrenic brain } 14,15 \\
\text { - Adjunctive medication of sigma-I ligands effective } \\
\text { for cognitive deficits of schizophrenia }{ }^{35-37}\end{array}$ \\
\hline \multirow[t]{2}{*}{$\begin{array}{l}\text { Major depressive } \\
\text { disorder }\end{array}$} & $\begin{array}{l}\text { Fluvoxamine } \\
\text { SA4503 } \\
\text { lgmesine (JO-I } 784) \\
\text { Neurosteroids }\end{array}$ & Preclinical & $\begin{array}{l}\text { - Sigma-I ligands show antidepressive effects in the } \\
\text { forced swimming test }{ }^{45-49} \\
\text { - Neurosteroids, considered as endogenous sigma-I } \\
\text { ligands, show antidepressive effects }{ }^{48,54}\end{array}$ \\
\hline & & Clinical & $\begin{array}{l}\text { - Psychotic major depression is improved } \\
\text { by fluvoxamine monotherapy }{ }^{62-64,66}\end{array}$ \\
\hline \multirow[t]{2}{*}{$\begin{array}{l}\text { Obsessive-compulsive } \\
\text { disorder }\end{array}$} & Fluvoxamine & Preclinical & $\begin{array}{l}\text { - Fluvoxamine improves marble-burying behavior in } \\
\text { mice through sigma-I receptor activity }{ }^{75}\end{array}$ \\
\hline & & Clinical & $\begin{array}{l}\text { - Fluvoxamine effective for obsessive-compulsive } \\
\text { disorder }{ }^{72} \\
\text { - Fluvoxamine enhances the effect of cognitive } \\
\text { behavioral therapy }{ }^{78,79}\end{array}$ \\
\hline \multirow[t]{2}{*}{ Alzheimer's disease } & Donepezil PRE-048 & Preclinical & $\begin{array}{l}\text { - Donepezil show neuroprotective properties } \\
\text { against } A \beta_{25-35} \text { peptide-induced toxicity } y^{82} \\
\text { - Donepezil show anti-amnesic effects which are } \\
\text { antagonized by sigma-I antagonists }{ }^{82}\end{array}$ \\
\hline & & Clinical & $\begin{array}{l}\text { - Decrease of sigma-I receptors in the Alzheimer's } \\
\text { disease brain }{ }^{85,86}\end{array}$ \\
\hline
\end{tabular}

Note: Summarized table of psychiatric diseases and relating substances and events regarding the sigma-I receptor. Abbreviation: NMDA, N-methyl-D-aspartate.

The typical treatment for psychotic major depression is to administer a combination of antipsychotics and antidepressants. However, this approach may lead to significant side effects, including EPS.

Interestingly, there are multiple reports showing that monotherapy with the selective serotonin reuptake inhibitor (SSRI) fluvoxamine was effective for the treatment of this disorder. ${ }^{62-64}$ Another SSRI, paroxetine, had a lesser effect. ${ }^{65}$ The reason underlying the difference in efficacy between these two SSRIs is currently unknown. Unlike paroxetine, which has an inhibition constant (Ki) of $1893 \mathrm{nM}$, fluvoxamine is a potent sigma-1 receptor agonist with a $\mathrm{Ki}$ of $36 \mathrm{nM},{ }^{66}$ suggesting that sigma-1 receptors are involved in the mechanisms of fluvoxamine's action. ${ }^{67}$ In addition, Shirayama and Hashimoto ${ }^{68}$ reported a case showing that fluvoxamine monotherapy was effective in a Japanese female patient with psychotic depression. Based on all these findings, it has been proposed that sigma-1 receptors may be implicated in the efficacy of fluvoxamine for psychotic major depression. ${ }^{69,70}$ These reports suggest that fluvoxamine monotherapy could be a good alternative approach for the treatment of psychotic depression, since it decreases the risk of EPS by obviating the need for antipsychotic drugs. Nevertheless, further detailed, double-blind studies will be needed to clarify the role of sigma-1 receptors in the efficacy of fluvoxamine for psychotic depression.

\section{Obsessive-compulsive disorder}

Obsessive-compulsive disorder (OCD) is an anxiety disorder characterized by obsessions and compulsions. Obsessions are recurrent and persistent thoughts, impulses, or images that are experienced, at some time during the disturbance, as intrusive and inappropriate and that cause marked anxiety or distress. Compulsions are repetitive behaviors (eg, hand washing, ordering, checking) or mental acts (eg, praying, counting, repeating words silently) that the person feels driven to perform in response to an obsession, or according to rules that must be applied rigidly. ${ }^{71}$ These acts are often performed in the hope of preventing or reducing anxiety or distress.

SSRIs are the first choice pharmaceutical treatment for OCD, and fluvoxamine has been tested in several dou- 
ble-blind, placebo-controlled and active-comparison studies. It was demonstrated that fluvoxamine had equal efficacy to clomipramine (a tricyclic antidepressant with potent serotonin reuptake inhibition) and other SSRIs (paroxetine and citalopram). ${ }^{72}$ As a result, fluvoxamine was the first SSRI to be approved for OCD. ${ }^{73}$ An extended release type of fluvoxamine, fluvoxamine $\mathrm{CR}$, has also been considered effective for OCD, and allows a higher starting dose without increasing the occurrence of side effects. ${ }^{74}$

In a preclinical study, Egashira and colleagues ${ }^{75}$ demonstrated that fluvoxamine ameliorated the marble-burying behavior in mice, which is considered to be a potential model of OCD, and that these ameliorating effects were antagonized by the sigma-1 receptor antagonist BD-1047 or BD-1063 (Figure 1) but not by the sigma-2 receptor antagonist SM-21. In the case of paroxetine administration, on the other hand, the marble-burying behavior was ameliorated, but the improvements were unaffected by BD-1047 or BD$1063 .^{75}$ These results strongly indicate that fluvoxamine has an additional therapeutic effect for OCD through sigma-1 receptors, which in turn indicates that sigma-1 receptors may be involved in the psychopathological symptoms of OCD.

Cognitive behavioral therapy (CBT) is effective for the treatment of OCD. ${ }^{76,77}$ Two placebo-controlled studies have reported that fluvoxamine enhances the effect of $\mathrm{CBT} .^{78,79}$ This is consistent with the multiple reports of fluvoxamine improving cognitive deficits via sigma-1 receptors. These reports suggest that sigma-1 receptors may be involved in the pathology of OCD, although further studies will be needed to confirm this.

\section{Alzheimer's disease}

Alzheimer's disease (AD) is a progressive and fatal neurodegenerative disorder mainly manifested by cognitive and memory deterioration. ${ }^{80}$ Research advances have revealed that the molecular pathogenesis of this disease principally involves amyloid $\beta(\mathrm{A} \beta)$ plaques and hyperphosphorylated tau tangles. ${ }^{81}$

Donepezil (Figure 1), an acetylcholinesterase (AChE) inhibitor, is the most widely prescribed drug for AD. ${ }^{81}$ Donepezil was found to have neuroprotective properties against $\mathrm{A} \beta_{25-35}$ peptide-induced toxicity in mice. ${ }^{82}$ In the same report, donepezil and the sigma-1 agonist PRE-048 (Figure 1), as well as the cholinesterase inhibitors tacrine, rivastigmine, and galantamine, showed antiamnesic effects. But only the effects of PRE-048 and donepezil were antagonized by the sigma-1 receptor antagonist BD-1047 (Figure 1). ${ }^{82}$ Also, when administered before $A \beta_{25-35}$ injection, only
PRE-048 and donepezil showed neuroprotective effects. This was confirmed by the blocking of lipid peroxidation and improvements of learning deficits, effects again inhibited by BD-1047. Administration of PRE-048 and donepezil after $\mathrm{A} \beta_{25-35}$ injection induced complete neuroprotection, whereas the other cholinesterase inhibitors showed only partial effects. ${ }^{82}$ Taken together, these findings suggest that the beneficial effects of donepezil occur via sigma-1 receptors and that the neuroprotection conferred by pre-administration of donepezil through sigma-1 receptors may lead to means of $\mathrm{AD}$ prevention.

We previously reported that donepezil, but not physostigmine, significantly potentiated NGF-induced neurite outgrowth in PC12 cells in a concentration-dependent manner, and that the effect of donepezil could be antagonized by NE-100. ${ }^{83}$ Furthermore, we reported that donepezil, but not physostigmine, significantly improved PCP-induced cognitive impairments in mice, and that the effect of donepezil could be antagonized by co-administration of NE-100. ${ }^{32}$ Our positron emission tomography (PET) study demonstrated that donepezil bound to sigma-1 receptors in the human brain in a dose-dependent manner. ${ }^{84}$ Therefore, it is likely that sigma-1 receptors are involved in the mechanism of the pharmacological action of donepezil in the human brain.

A postmortem has revealed that the density of sigma-1 receptors is reduced in the hippocampus of patients with AD. ${ }^{85}$ Mishina and colleagues ${ }^{86}$ reported in a study using $\left[{ }^{11} \mathrm{C}\right] \mathrm{SA} 4503$ and PET that AD patients had a lower density of sigma-1 receptors than age-matched controls. A further PET study using drug-untreated patients with AD would be of interest, because some patients in this report were receiving donepezil treatment.

\section{PET study of sigma-I receptors in the human brain}

$\mathrm{PET}$ is a noninvasive imaging technique which produces functional process images by detecting gamma rays emitted from positron emitting tracers. Because the main positron-emitting radionuclides $\left({ }^{11} \mathrm{C},{ }^{13} \mathrm{~N},{ }^{15} \mathrm{O},{ }^{18} \mathrm{~F}\right)$ used in PET are elements found within a living organism, PET is useful for quantitative measurement of physiological and biochemical information. PET can also measure neural receptors in the brain quantitatively and can calculate the receptor occupancy of target drugs. Therefore, in order to unravel the relation between sigma-1 receptors and various neuropsychiatric diseases, PET imaging should be used to image the cerebral distribution of sigma-1 receptors and 
to examine the disease-related changes in the distribution of sigma-1 receptors.

Development of PET tracers to measure sigma-1 receptors began in the $1980 \mathrm{~s}$, and it was subsequently established that ${ }^{11} \mathrm{C}$-labeled 1-(3,4-dimethoxyphenethyl)4-(3-phenylpropyl)piperazine $\left(\left[{ }^{11} \mathrm{C}\right] \mathrm{SA} 4503\right)$ is useful for this purpose. ${ }^{87-90}$ Ishiwata and colleagues ${ }^{90}$ reported a high occupancy of sigma-1 receptors (approximately 80\%) as well as dopamine $\mathrm{D}_{2}$ receptors (approximately 60\%) in the human brain after a single oral administration of haloperidol (3 mg), suggesting that a PET study with $\left[{ }^{11} \mathrm{C}\right] \mathrm{SA} 4503$ can be used for evaluating the sigma-1 receptor occupancy by therapeutic drugs in the human brain. Subsequently, we have used $\left[{ }^{11} \mathrm{C}\right] \mathrm{SA} 4503-\mathrm{PET}$ to evaluate successfully the sigma-1 receptor occupancy by fluvoxamine ${ }^{91}$ and donepezil, ${ }^{84}$ demonstrating that fluvoxamine and donepezil bind to sigma-1 receptors in the human brain at therapeutic doses (Figures 4 and 5). These findings suggest that sigma1 receptors may be involved in the mechanism of action of fluvoxamine and donepezil. Finally, it is very important to investigate whether sigma-1 receptor density is altered in the brains of patients with schizophrenia, major depression, OCD, or AD using $\left[{ }^{11} \mathrm{C}\right] \mathrm{SA} 4503-\mathrm{PET}$.

\section{Conclusion}

As described above, the unique ER protein sigma-1 receptors are assumed to serve as a regulator of ATP production and bioenergetics within the cell, ${ }^{1,12}$ and sigma-1 receptors may play a key role in the pathophysiology of some neuropsychiatric diseases. Furthermore, sigma-1 receptor agonists have been implicated in the enhancement of neuroplasticity and cognitive functioning. The clinical potential of sigma-1

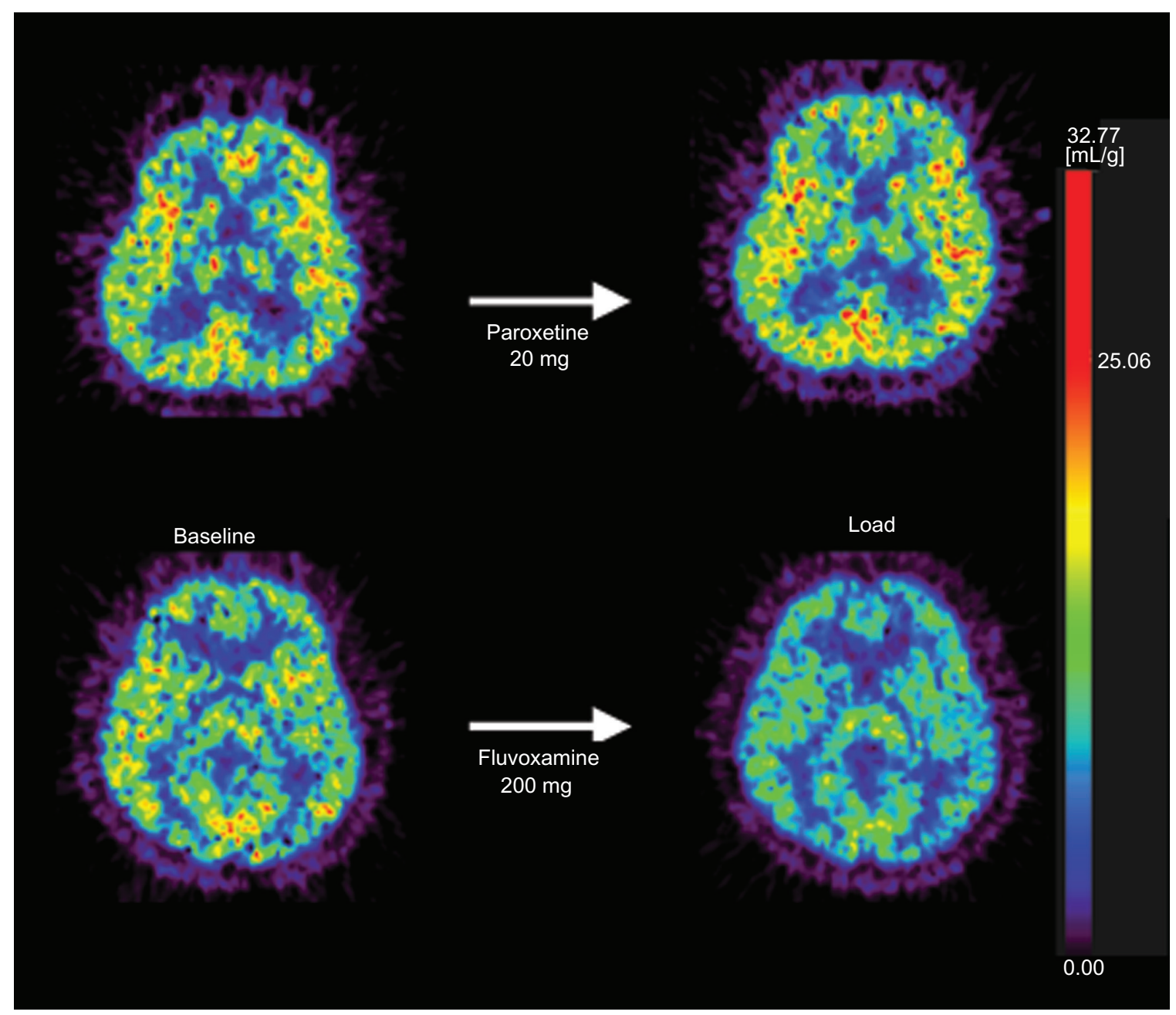

Figure 4 The ["C]SA4503-PET (positron emission tomography) images of before and after taking a selective serotonin reuptake inhibitor (SSRI). Volume of distribution images of [ ' C]SA4503-PET before and after a single oral administration of an SSRI. The upper pair represents images at baseline (left) and at paroxetine (20 mg)-loading (right) in the same subject. The lower pair shows images at baseline (left) and fluvoxamine ( $200 \mathrm{mg}$ )-loading (right) in another subject. Note that while paroxetine does not effect ["C]SA4503 binding, fluvoxamine obstructs the ["C]SA4503 binding because fluvoxamine itself binds to sigma-I receptors. 


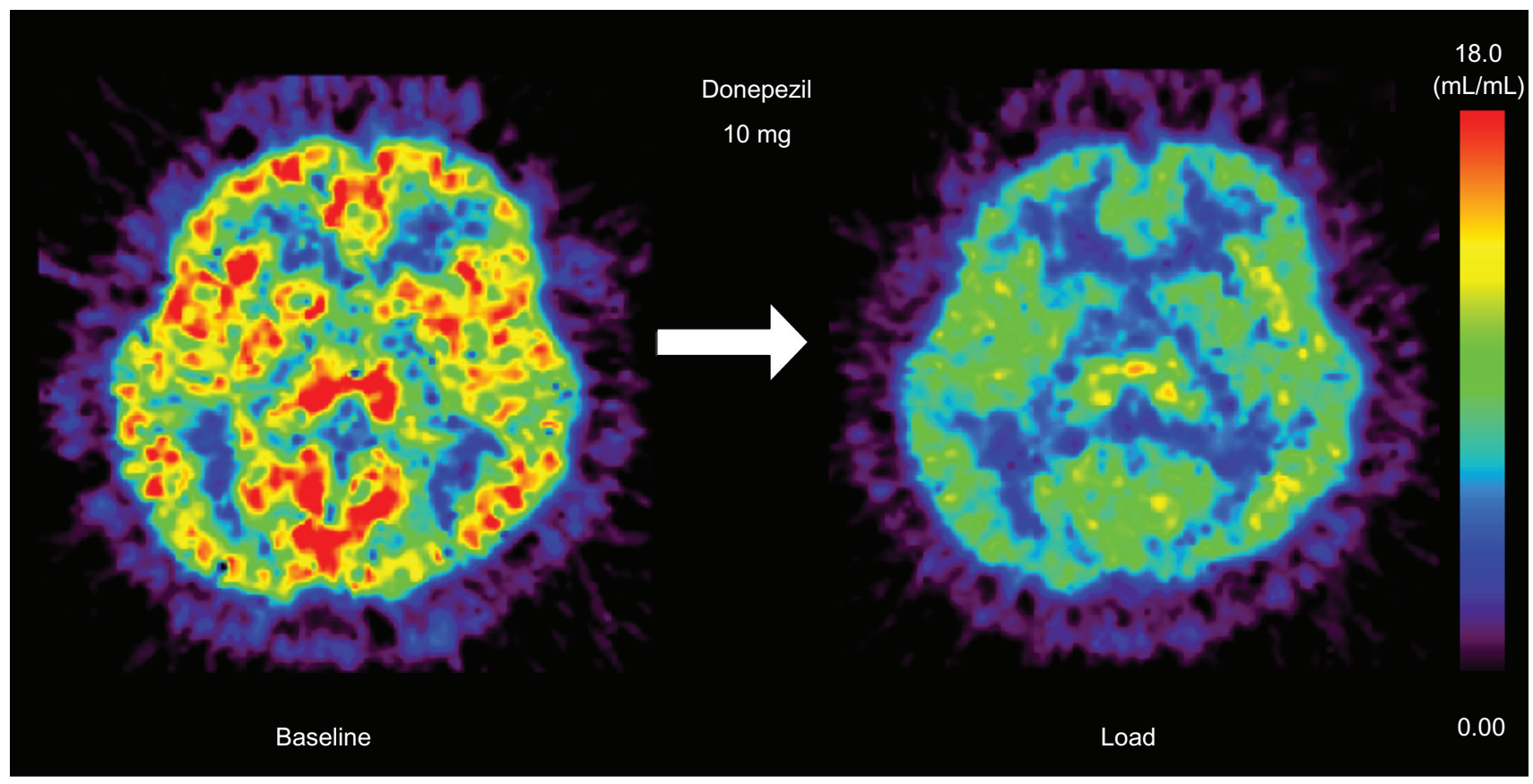

Figure 5 The [" C]SA4503-PET images of before and after taking denepezil. Representative images of the volume of distribution of [" C]SA4503-PET before (left) and after (right) a single oral administration of donepezil $(10 \mathrm{mg})$ in a healthy subject.

receptor agonists is only just beginning to be explored. The primary therapeutic targets of sigma-1 receptor agonists in ongoing research include schizophrenia, major depression, $\mathrm{OCD}$, and AD.

\section{Disclosures}

The authors report no conflicts of interest in this work.

\section{References}

1. Hayashi T, Su TP. Sigma-1 receptor chaperones at the ER-mitochondrion interface regulate $\mathrm{Ca}^{2+}$ signaling and cell survival. Cell. 2007;131(3): 596-610.

2. Martin WR, Eades CG, Thompson JA, et al. The effects of morphine- and nalmorphine-like drugs in the nondependent and morphine-dependent chronic spinal dog. J Pharmacol Exp Ther. 1976;197(3):517-532.

3. Su TP. Evidence for sigma opioid receptor: binding of $\left[{ }^{3} \mathrm{H}\right] \mathrm{SKF}-10047$ to etorphine-inaccessible sites in guinea-pig brain. J Pharmacol Exp Ther. 1982;223(2):284-290.

4. Vaupel DB. Naltrexone fails to antagonize the sigma effects of PCP and SKF 10,047 in the dog. Eur J Pharmacol. 1983;92(3-4):269-274.

5. Wong EH, Knight AR, Woodruff GN. $\left[{ }^{3} \mathrm{H}\right] \mathrm{MK}-801$ labels a site on the $\mathrm{N}$-methyl-D-aspartate receptor channel complex in rat brain membranes. J Neurochem. 1988;50(1):274-281.

6. Gundlach AL, Largent BL, Snyder SH. Phencyclidine and sigma opiate receptors in brain: biochemical and autoradiographical differentiation. Eur J Pharmacol. 1985;113(3):465-466.

7. Quirion R, Bowen WD, Itzhak Y, et al. A proposal for the classification of sigma binding sites. Trends Pharmacol Sci. 1992;13(3):85-86.

8. Bowen WD, Hellewell SB, McGarry KA. Evidence for a multi-site model of the rat brain sigma receptor. Eur J Pharmacol. 1989;163(2-3): 309-318.

9. Hanner M, Moebius FF, Flandorfer A, et al. Purification, molecular cloning, and expression of the mammalian sigma1-binding site. Proc Natl Acad Sci U S A. 1996;93(15):8072-8077.
10. Hayashi T, Su TP. Intracellular dynamics of sigma-1 receptors (sigma-1 binding sites) in NG108-15 cells. J Pharmacol Exp Ther. 2003;306(2): 726-733.

11. Hayashi T, Su TP. Sigma-1 receptors (sigma-1 binding sites) form raft-like microdomains and target lipid droplets on the endoplasmic reticulum: roles in endoplasmic reticulum lipid compartmentalization and export. J Pharmacol Exp Ther. 2003;306(2):718-725.

12. Hayashi T, Stahl SM. The sigma-1 receptor and its role in the treatment of mood disorders. Drugs Future. 2009;34(29):137-146.

13. Regier DA, Narrow WE, Rae DS, Manderscheid RW, Locke BZ, Goodwin FK. The de facto US mental and addictive disorders service system. Epidemiologic Catchment Area prospective 1-year prevalence rates of disorders and services. Arch Gen Psychiatry. 1993;50(2): $85-94$.

14. Weissman AD, Casanova MF, Kleinman JE, et al. Selective loss of cerebral cortical sigma, but not PCP binding sites in schizophrenia. Biol Psychiatry. 1991;29(1):41-54.

15. Shibuya H, Mori H, Toru M. Sigma receptors in schizophrenic cerebral cortices. Neurochem Res. 1992;17(10):983-990.

16. Tam SW, Cook L. Sigma opiates and certain antipsychotic drugs mutually inhibit $(+)-\left[{ }^{3} \mathrm{H}\right]$ SKF 10,047 and $\left[{ }^{3} \mathrm{H}\right]$ haloperidol binding in guinea pig brain membranes. Proc Natl Acad Sci U SA. 1984;81(17): $5618-5621$.

17. Shimazu S, Katsuki H, Takenaka C, et al. Sigma receptor ligands attenuate N-methyl-D-aspartate cytotoxicity in dopaminergic neurons of mesencephalic slice cultures. Eur J Pharmacol. 2000;388(2):139-146.

18. Urani A, Romieu P, Portales-Casamar E, et al. The antidepressant-like effect induced by the sigma-1 (sigma-1) receptor agonist igmesine involves modulation of intracellular calcium mobilization. Psychopharmacology (Berl). 2002;163(1):26-35.

19. Moison D, De Deurwaerdère P, Cagnotto A, et al. Intrastriatal administration of sigma ligands inhibits basal dopamine release in vivo. Neuropharmacology. 2003;45(7):945-953.

20. Javitt DC, Zukin SR. Recent advances in the phencyclidine model of schizophrenia. Am J Psychiatry. 1991;148(10):1301-1308.

21. Olney JW, Farber NB. Glutamate receptor dysfunction and schizophrenia. Arch Gen Psychiatry. 1995;52(12):998-1007. 
22. Goff DC, Coyle JT. The emerging role of glutamate in the pathophysiology and treatment of schizophrenia. Am J Psychiatry. 2001;158(9): 1367-1377.

23. Hashimoto K, Fukushima T, Shimizu E, et al. Decreased serum levels of D-serine in patients with schizophrenia: evidence in support of the NMDA receptor hypofunction hypothesis of schizophrenia. Arch Gen Psychiatry. 2003;60(6):572-576.

24. Hashimoto K, Okamura N, Shimizu E, et al. Glutamate hypothesis of schizophrenia and approach for possible therapeutic drugs. Curr Med Chem CNS Agents. 2004;4(2):147-154.

25. Hashimoto K, Shimizu E, Iyo M. Dysfunction of glia-neuron communication in pathophysiology of schizophrenia. Curr Psychiatry Rev. 2005;1(2):151-163.

26. Hashimoto K. The NMDA receptor hypofunction hypothesis for schizophrenia and glycine modulatory sites on the NMDA receptors as potential therapeutic drugs. Clin Psychopharmacol Neurosci. 2006; 4(1):3-10.

27. Hayashi T, Su TP. Sigma-1 receptor ligands: potential in the treatment of neuropsychiatric disorders. CNS Drugs. 2004;18(5):269-284.

28. Modell S, Naber D, Holzbach R. Efficacy and safety of an opiate sigma-receptor antagonist (SL 82.0715) in schizophrenic patients with negative symptoms: an open dose-range study. Pharmacopsychiatry. 1996;29(2):63-66.

29. Huber MT, Gotthardt U, Schreiber W, et al. Efficacy and safety of the sigma receptor ligand EMD 57445 (panamesine) in patients with schizophrenia: an open clinical trial. Pharmacopsychiatry. 1999; 32(2):68-72.

30. Green MF. What are the functional consequences of neurocognitive deficits in schizophrenia? Am J Psychiatry. 1996;153(3): 321-330.

31. Ishima T, Fujita Y, Kohno M, et al. Improvement of phencyclidineinduced cognitive deficits in mice by subsequent subchronic administration of fluvoxamine, but not sertraline. Open Clin Chem J. 2009; 2(5):7-11.

32. Kunitachi S, Fujita Y, Ishima T, et al. Phencyclidine-induced cognitive deficits in mice are ameliorated by subsequent subchronic administration of donepezil: role of sigma-1 receptors. Brain Res. 2009;1279: 189-196.

33. Hashimoto K, Fujita Y, Iyo M. Phencyclidine-induced cognitive deficits in mice are improved by subsequent subchronic administration of fluvoxamine: role of sigma-1 receptors. Neuropsychopharmacology. 2007;32(3):514-551.

34. Okuyama S, Nakazato A. NE-100: a novel sigma receptor antagonist. CNS Drug Rev. 1996;2(2):226-237.

35. Silver H, Barash I, Aharon N, et al. Fluvoxamine augmentation of antipsychotics improves negative symptoms in psychotic chronic schizophrenic patients: a placebo-controlled study. Int Clin Psychopharmacol. 2000;15(5):257-261.

36. Silver H. Fluvoxamine as an adjunctive agent in schizophrenia. CNS Drug Rev. 2001;7(3):283-304.

37. Iyo M, Shirayama Y, Watanabe $\mathrm{H}$, et al. Fluvoxamine as a sigma-1 receptor agonist improved cognitive impairments in a patient with schizophrenia. Prog Neuropsychopharmacol Biol Psychiatry. 2008; 32(4):1072-1073.

38. Shirayama Y, Takahashi K, Nishikawa T. Uncompetitive inhibition of

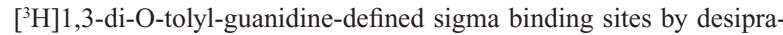
mine, propranolol and alprenolol in rat brain. Eur J Pharmacol. 1997; 331(2-3):319-323.

39. Ishiguro $H$, Ohtsuki $\mathrm{T}$, Toru M, et al. Association between polymorphisms in the type 1 sigma receptor gene and schizophrenia. Neurosci Lett. 1998;257(1):45-48.

40. Ohmori O, Shinkai T, Suzuki T, et al. Polymorphisms of the sigma-1 receptor gene in schizophrenia: An association study. Am J Med Genet. 2000;96(1):118-122.

41. Satoh F, Miyatake R, Furukawa A, et al. Lack of association between sigma receptor gene variants and schizophrenia. Psychiatry Clin Neurosci. 2004;58(4):359-363.
42. Takizawa R, Hashimoto K, Tochigi M, et al. Association between sigma-1 receptor gene polymorphism and prefrontal hemodynamic response induced by cognitive activation in schizophrenia. Prog Neuropsychopharmacol Biol Psychiatry. 2009;33(3):491-498.

43. World Health Organization. The World Health Report: 2004: Changing History, Annex Table 3: Burden of disease in DALYs by cause, sex, and mortality stratum in WHO regions, estimates for 2002. Geneva, Switzerland: World Health Organization; 2004.

44. Kessler RC, Chiu WT, Demler O, Walters EE. Prevalence, severity, and comorbidity of twelve-month DSM-IV disorders in the National Comorbidity Survey Replication (NCS-R). Arch Gen Psychiatry. 2005; 62(6):617-627.

45. Matsuno K, Kobayashi T, Tanaka MK, et al. Sigma-1 receptor subtype is involved in the relief of behavioral despair in the mouse forced swimming test. Eur J Pharmacol. 1996;312(3):267-271.

46. Roman FJ, Pascaud X, Martin B, et al. JO 1784, a potent and selective ligand for rat and mouse brain sigma-sites. J Pharm Pharmacol. 1990; 42(6):439-440.

47. Matsuno K, Nakazawa M, Okamoto K, et al. Binding properties of SA4503, a novel and selective sigma 1 receptor agonist. Eur $J$ Pharmacol. 1996;306(1-3):271-279.

48. Urani A, Roman FJ, Phan VL, et al. The antidepressant-like effect induced by sigma-1 receptor agonists and neuroactive steroids in mice submitted to the forced swimming test. J Pharmacol Exp Ther. 2001;298(3):1269-1279.

49. Tottori K, Miwa T, Uwahodo Y, et al. Antidepressant-like responses to the combined sigma and $5-\mathrm{HT}_{1 \mathrm{~A}}$ receptor agonist OPC-14523. Neuropharmacology. 2001;41(8):976-988.

50. Bermack JE, Debonnel G. The role of sigma receptors in depression. J Pharmacol Sci. 2005;97(3):317-336.

51. Sabino V, Cottone P, Parylak SL, et al. Sigma-1 receptor knockout mice display a depressive-like phenotype. Behav Brain Res. 2009;198(2): $472-476$.

52. Nishimura T, Ishima T, Iyo M, et al. Potentiation of nerve growth factor-induced neurite outgrowth by fluvoxamine: role of sigma-1 receptors, $\mathrm{IP}_{3}$ receptors and cellular signaling pathways. PLoS One. 2008; 3(7):e2558.

53. Baulieu EE. Neurosteroids: a novel function of the brain. Psychoneuroendocrinology. 1998;23(8):963-987.

54. Reddy DS, Kaur G, Kulkarni SK. Sigma (sigma-1) receptor mediated anti-depressant-like effects of neurosteroids in the Porsolt forced swim test. J Pharmacol Exp Ther. 2001;298(3):1269-1279.

55. Guitart X, Codony X, Monroy X. Sigma receptors: biology and therapeutic potential. Psychopharmacology (Berl). 2004;174(3): 301-319.

56. Skuza G, Wedzony K. Behavioral pharmacology of sigma-ligands Pharmacopsychiatry. 2004;37(Suppl 3):S183-S188.

57. Hashimoto K, Ishiwata K. Sigma receptor ligands: possible application as therapeutic drugs and as radiopharmaceuticals. Curr Pharm Des. 2006;12(30):3857-3876.

58. Cobos EJ, Entrena JM, Nieto FR, et al. Pharmacology and therapeutic potential of sigma(1) receptor ligands. Curr Neuropharmacol. 2008; 6(4):344-366

59. Maurice T, Su TP. The pharmacology of sigma-1 receptors. Pharmacol Ther. 2009;124(2):195-206.

60. Schatzberg AF. New approaches to managing psychotic depression. J Clin Psychiatry. 2003;64(Suppl 1):19-23.

61. Vythilingam M, Chen J, Bremner JD, et al. Psychotic depression and mortality. Am J Psychiatry. 2003;160(3):574-576.

62. Gatti F, Bellini L, Gasperini M, et al. Fluvoxamine alone in the treatment of delusional depression. Am J Psychiatry. 1996;153(3):414-416.

63. Hirschfeld RM. Efficacy of SSRIs and newer antidepressants in severe depression: Comparison with TCAs. J Clin Psychiatry. 1999;60(5): 326-335.

64. Zanardi R, Franchini L, Gasperini M, et al. Faster onset of action of fluvoxamine in combination with pindolol in the treatment of delusional depression: A controlled study. J Clin Psychopharmacol. 1998;18(6):441-446. 
65. Zanardi R, Franchini L, Gasperini M, et al. Double-blind controlled trial of sertraline versus paroxetine in the treatment of delusional depression. Am J Psychiatry. 1996;153(12):1631-1633.

66. Narita N, Hashimoto $\mathrm{K}$, Tomitaka S, et al. Interactions of selective serotonin reuptake inhibitors with subtypes of sigma receptors in rat brain. Eur J Pharmacol. 1996;307(1):117-119.

67. Hashimoto K. Sigma-1 receptors and selective serotonin reuptake inhibitors: clinical implications of their relationship. Cent Nerv Syst Agents Med Chem. 2009;9(3):197-204.

68. Shirayama Y, Hashimoto K. A case of psychotic depression treated with fluvoxamine monotherapy. Clin Psychopharmacol Neurosci. In press 2010.

69. Stahl SM. Antidepressant treatment of psychotic major depression: Potential role of the sigma receptor. CNS Spectr. 2005;10(4):319-323.

70. Hayashi T, Su TP. Understanding the role of sigma-1 receptors in Psychotic depression. Psychiatr Times. 2005;22(11):54-63.

71. American Psychiatric Association. Diagnostic and Statistical Manual of Mental Disorders. 4th edition. Washington DC: American Psychiatric Publishing; 2000.

72. Dell'Osso B, Allen A, Hollander E. Fluvoxamine: a selective serotonin re-uptake inhibitor for the treatment of obsessive-compulsive disorder. Expert Opin Pharmacother. 2005;6(15):2727-2740.

73. Irons J. Fluvoxamine in the treatment of anxiety disorders. Neuropsychiatr Dis Treat. 2005;1(4):289-299.

74. Ordacgi L, Mendlowicz MV, Fontenelle LF. Management of obsessivecompulsive disorder with fluvoxamine extended release. Neuropsychiatr Dis Treat. 2009;5:301-308.

75. Egashira N, Harada S, Okuno R, et al. Involvement of the sigma1 receptor in inhibiting activity of fluvoxamine on marble-burying behavior: comparison with paroxetine. Eur J Pharmacol. 2007;563(1-3):149-154.

76. Simpson HB, Foa EB, Liebowitz MR, et al. A randomized, controlled trial of cognitive-behavioral therapy for augmenting pharmacotherapy in obsessive-compulsive disorder. Am J Psychiatry. 2008;165(5): 621-630.

77. Clark DA. Cognitive-Behavioral Therapy for OCD. New York, NY: Guilford; 2004.

78. Cottraux J, Mollard E, Bouvard M, et al. Exposure therapy, fluvoxamine, or combination treatment in obsessive-compulsive disorder: one-year follow-up. Psychiatry Res. 1993;49(1):63-75.

79. Hohagen F, Winkelmann G, Rasche-Rüchle H, et al. Combination of behaviour therapy with fluvoxamine in comparison with behaviour therapy and placebo. Results of a multicentre study. Br J Psychiatry Suppl. 1998;(35):71-78.
80. Cummings JL. Alzheimer's disease. N Engl J Med. 2004;351(1):56-67.

81. Blennow K, de Leon MJ, Zetterberg H. Alzheimer's disease. Lancet. 2006;368(9533):387-403

82. Meunier J, Ieni J, Maurice T. The anti-amnesic and neuroprotective effects of donepezil against amyloid beta ${ }_{25-35}$ peptide-induced toxicity in mice involve an interaction with the sigmal receptor. Br J Pharmacol. 2006;149(8):998-1012.

83. Ishima T, Nishimura T, Iyo M, Hashimoto $\mathrm{K}$. Potentiation of nerve growth factor-induced neurite outgrowth in PC12 cells by donepezil: role of sigma-1 receptors and $\mathrm{IP}_{3}$ receptors. Prog Neuropsychopharmacol Biol Psychiatry. 2008;32(7):1656-1659.

84. Ishikawa M, Sakata M, Ishii K, et al. High occupancy of sigma-1 receptors in the human brain after single oral administration of donepezil: a positron emission tomography study using $\left[{ }^{11} \mathrm{C}\right] \mathrm{SA} 4503$. Int $J$ Neuropsychopharmacol. 2009;12(8):1127-1131.

85. Jansen KL, Faull RL, Storey P, et al. Loss of sigma binding sites in the CA1 area of the anterior hippocampus in Alzheimer's disease correlates with CA1 pyramidal cell loss. Brain Res. 1993;623(2):299-302.

86. Mishina M, Ohyama M, Ishii K, et al. Low density of sigma1 receptors in early Alzheimer's disease. Ann Nucl Med. 2008;22(3):151-156.

87. Kawamura K, Ishiwata $\mathrm{K}$, Tajima $\mathrm{H}$, et al. In vivo evaluation of $\left[{ }^{11} \mathrm{C}\right] \mathrm{SA} 4503$ as a PET ligand for mapping CNS sigma-1 receptors. Nucl Med Biol. 2000;27(3):255-261.

88. Kawamura K, Elsinga PH, Kobayashi T, et al. Synthesis and evaluation of ${ }^{11} \mathrm{C}$ - and ${ }^{18} \mathrm{~F}$-labeled 1-[2-(4-alkoxy-3-methoxyphenyl)ethyl]4-(3-phenylpropyl)piperazines as sigma receptor ligands for positron emission tomography studies. Nucl Med Biol. 2003;30(3):273-284.

89. Ishiwata K, Ishii K, Kimura Y, et al. Successive positron emission tomography measurement of cerebral blood flow and neuroreceptors in the human brain: an ${ }^{11} \mathrm{C}-\mathrm{SA} 4503$ study. Ann Nucl Med. 2008;22(5): $411-416$.

90. Ishiwata K, Oda K, Sakata M, et al. A feasibility study of $\left[{ }^{11} \mathrm{C}\right] \mathrm{SA} 4503$ PET for evaluating sigmal receptor occupancy by neuroleptics: the binding of haloperidol to sigma-1 and dopamine $\mathrm{D}_{2}$-like receptors. Ann Nucl Med. 2006;20(8):569-573.

91. Ishikawa $M$, Ishiwata $\mathrm{K}$, Ishii $\mathrm{K}$, et al. High occupancy of sigma-1 receptors in the human brain after single oral administration of fluvoxamine: a positron emission tomography study using $\left[{ }^{11} \mathrm{C}\right] \mathrm{SA} 4503$. Biol Psychiatry. 2007;62(8):878-883.
Journal of Receptor, Ligand and Channel Research

\section{Publish your work in this journal}

The Journal of Receptor, Ligand and Channel Research is an international, peer-reviewed, open access, online journal. The journal welcomes laboratory and clinical findings in the fields of biological receptors, ligands, channel and signal transduction research including: receptors and signalling; ligands; transporters, pores and channels; binding and activation; receptor

\section{Dovepress}

regulation; role of receptors in diseases and their treatment; molecular basis of membrane structure and functions; molecular models of membranes. The manuscript management system is completely online and includes a very quick and fair peer-review system. Visit http://www.dovepress.com/ testimonials.php to read real quotes from published authors. 